\title{
Woodinine and its Stereomers - Absolute Configuration
}

Siavosh Mahboobi ${ }^{*}$, Thomas Burgemeister, and Wolfgang Wiegrebe

Faculty of Chemistry and Pharmacy, University, P.O. Box 1010 42, D-8400 Regensburg/Germany

Received August 6, 1992

The synthesis of all the four stereomers of the alkaloid woodinine $(\mathbf{1 2 a})^{1)}$ is described and the stereochemical conclusions of $P a \ddot{i s}^{3)}$ and $S t i l{ }^{6)}$ are discussed. The absol. configurations of woodinine (12a) and its diastereomer $\mathbf{8 b}$ are unequivocally deduced from the pertinent piperazinediones $\mathbf{1 6}$ and 17.
Woodinin und seine Stereomeren - Absolute Konfiguration

Die Synthese aller vier Stereomerer des Alkaloids Woodinin $(\mathbf{1 2 a})^{1)}$ wird beschrieben, die stereochemischen Rückschlüsse von Païs ${ }^{3)}$ bzw. Still ${ }^{6}$ ) werden diskutiert. Anhand der Piperazindione 16 and 17 wird die absol. Konfiguration von Woodinin (12a) und des Diastereomers $\mathbf{8 b}$ bewiesen.
Recently we have described the synthesis of the alkaloid woodinine (12a, Scheme 2) ${ }^{1}$. The key step was the condensation of 5-bromotryptamine (1) with (S)-(-)-N-Boc-pyrrolidine-2-carboxaldehyde ${ }^{1)}$.
When we condensed 5-bromotryptamine (1) with $R-(+)$ $N$-Boc-pyrrolidine-2-carboxaldehyde (2) (Scheme 1), prepared from D-proline as described for the $S$-enantiomer ${ }^{1)}$, we<smiles>NCCc1c[nH]c2ccc(Br)cc12</smiles>

1<smiles>O=C[C@H]1CCCN1S(=O)(=O)O</smiles>

2

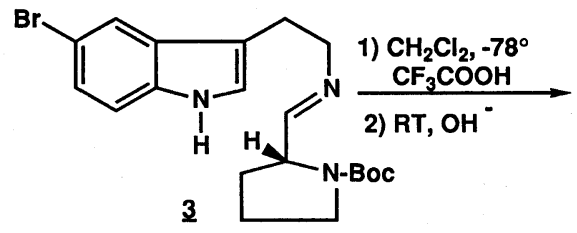

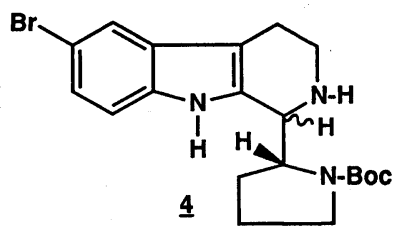

B

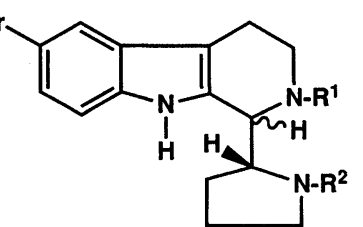

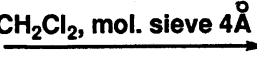
RT 1) $\mathrm{OHC}-\mathrm{O}-\mathrm{COCH}_{3}$ 2) $\mathrm{CF}_{3} \mathrm{COOH}, \mathrm{O}^{\circ}, \mathrm{N}_{2}(6)$

3) $\mathrm{OHC}-\mathrm{O}-\mathrm{COCH}_{3}(7)$ 5: $\mathbf{R}^{1}=\mathrm{CHO}, \mathrm{R}^{2}=\mathrm{BOC}$

6: $R^{1}=\mathrm{CHO}, \mathrm{R}^{2}=\mathrm{H}$

7: $\mathbf{R}^{\mathbf{1}}=\mathbf{R}^{\mathbf{2}}=\mathrm{CHO}$

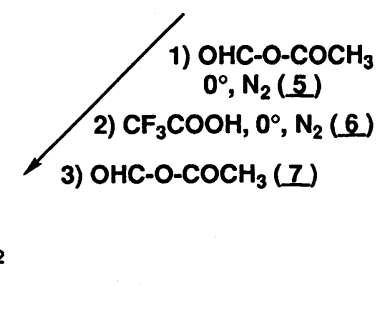

$$
\text { c }
$$


have obtained the Schiff-base 3 which was cyclized under the condi-tions cited ${ }^{1)}$ affording the diastereomers of compound 4 . These $s e c$. amines were $N$-formylated to compounds 5. - Deviating from our earlier procedure ${ }^{1)} 5$ was hydrolyzed by $\mathrm{CF}_{3} \mathrm{COOH}$ to amine 6 (this hydrolysis did not work with compound 4 ; here a useless mixture of compounds arose). After a second formylation (cpd. 7) the diastereomers were separated by flash-chromatography, whilst all our efforts to separate cpds. 5 and $\mathbf{9}$ (see below, Scheme 2) failed.

Diastereomers 7a and $\mathbf{7 b}$ were reduced with $\mathrm{LiAlH}_{4}$ within $1 \mathrm{~h}$ producing the enantiomer 8a of natural woodinine (12a) and its 1-(R)-2'-(R)-diastereomer 8b. - Woodinine (12a) and its stereomers will be tested by microbiologists for antibacterial activity in comparison with woodinine (12a) which is effective against Mycobacterium tuberculosis ${ }^{2}$.

Hydrolytic removal of the $N$-Boc-protecting group with subsequent formylation to 7, e.g. (Scheme 1) followed by reduction is superior to direct reduction of $N$-formyl- $N^{\prime}$ Boc-compounds (5, e.g.) with $\mathrm{LiAlH}_{4}{ }^{1)}$ ) (mild reduction of a pyrrolidine- $\mathrm{N}$-Boc/piperidine- $\mathrm{N}-\mathrm{CHO}$-derivative $\left(\mathbf{9}^{1)}\right.$, e.g.) with $\mathrm{LiAlH}_{4}$ in refluxing tetrahydrofurane for $1 \mathrm{~h}$ reduces the $\mathrm{N}$-CHO-increment leaving the $\mathrm{N}$-Boc-protecting group unaffected, so yielding 9'). Therefore, we used the route via the bis-formyl compounds also for the preparation of natu-ral woodinine (12a). - Separation of the $N, N^{\prime}$ bis-formyl compounds 11 (mixture of diastereomers with $S$ configuration in the pyrrolidine increment, obtained from cpd. 9 via amine 10) and subsequent $\mathrm{LiAlH}_{4}$-reduction affor- ded woodinine (12a) and the enantiomer $12 \mathbf{b}$ of diastereomer $8 \mathbf{b}$. By this route cpd. 12b (C-1-epimer of natural woodinine 12a) which was available in trace quantities only according to our earlier procedure ${ }^{1)}$ (cpd. 9a in lit. ${ }^{1)}$ ) can be obtained in $95 \%$ yield. - To our knowledge epiwoodinine $(\mathbf{8 b})$ or its enantiomer $\mathbf{1 2 b}$ have not yet been found in nature.

\section{Stereochemistry}

Concerning the stereochemistry of woodinine (12a) some questions arise from the published data:

Mme Païs et al. ${ }^{3)}$ present a formula of woodinine (cpd. 2 in their publication $^{3)}$ ) indicating $\alpha$-configuration for $\mathrm{H}-1$ of the tetrahydro- $\beta$-carboline ring. On the other side, however, they point out: “...la courbe de dc, qui présente un effet Cotton positif à $243 \mathrm{~nm}$, permet de préciser que l'hydrogene en 1 est en position $\beta{ }^{33)}$. - Païs quotes Rinehart $J r$. et al. ${ }^{4)}$ who describe structure elucidations of eudistomines and their O-acetyl derivatives, respectively (see cpds. 3 and 4 in lit. $\left.{ }^{4}\right)$ : “...The $\mathrm{CD}$ spectra $(\mathrm{MeOH})$ of 3 and 4 show a positive Cotton effect in the $240-300 \mathrm{~nm}$ region, indicating an $\alpha$-configuration for $\mathrm{H}-1$." So Rinehart's statement is contradictory to Païs' text but corroborates her formula shown ${ }^{3)}$.

Paï $^{3)}$ cites Bláha et al. ${ }^{5)}$ who deal with 5,16-cyclocorynane alkaloids. Bláha and coworkers represent the CD-spectrum of "(+)"-1-methyl$1,2,3,4$-tetrahydro- $\beta$-carboline with $\alpha$-configuration for $\mathrm{H}-1$ (called " $3 \alpha \mathrm{H}$ " by Bláha because $\mathrm{H}-1$ of tetrahydro- $\beta$-carbolines is numbered $\mathrm{H}-3$ in 5,16 cyclocorynanes): this spectrum clearly indicates a positive Cotton effect at about $240 \mathrm{~nm}$. Unfortunately these data cannot be used for comparison because in the Experimental Part of Bláha's publication " " $3 \beta \mathrm{H}$ " configuration is attributed to " $(+)$ "-1,2,3,4-tetrahydroharmane (= 1-methyl-1,2,3,4tetrahydro- $\beta$-carboline). This is a contradiction in terms. So, only the cyclocorynanes with $\alpha$-configuration for $\mathrm{H}-3$ can be used for correlation:
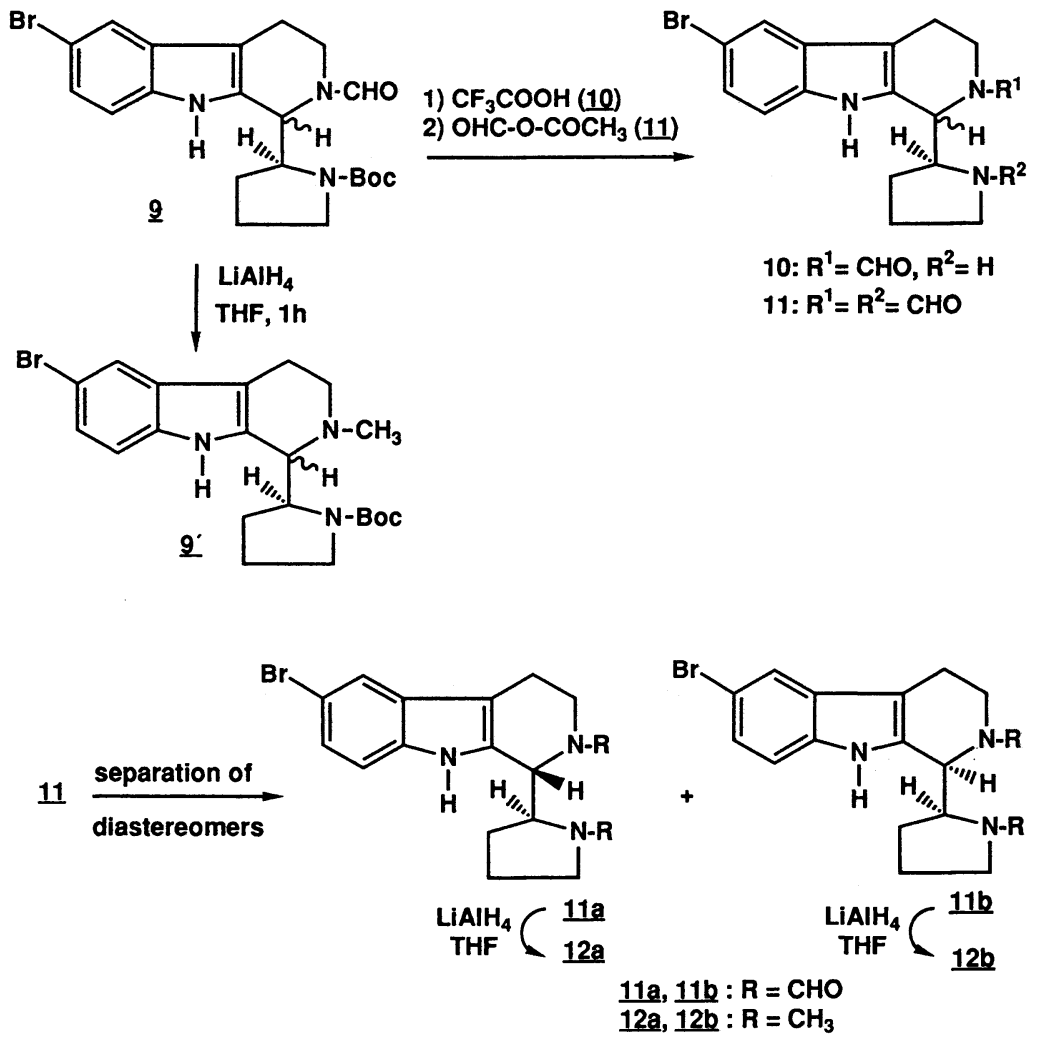

Scheme 2 
"In the whole series, the absolute configuration on the $\mathrm{C}_{(3)}$ atom is the same (S),,..$\left.{ }^{5}\right)$ ). - It should be realized, however, that these heterocycles contain the $\mathrm{C}-\mathrm{H}$-increment under consideration as part of an annelated ring system. This holds true also for the eudistomines ${ }^{4}$.

In 1991 Still et al. ${ }^{6}$ have reported on the synthesis of woodinine (12a) and of its epimer, starting from L-prolinal. Still ${ }^{6)}$ expected to get woodinine (12a) as the main diastereomer: "Based upon several known diastereoselective Pictet-Spengler reactions with chiral $\alpha$-amino aldehydes it appears that...D-amino aldehydes give the major product having the $\mathrm{C}-1$ hydrogen in the $\alpha$-position while the L-aldehydes...give the major product having the C-1 hydrogen $\beta, \ldots$. . - This assumption proved to be correct: $55 \%$ of woodinine (12a) - identified by comparison of NMR-data and optical rotation with Païs' data ${ }^{3)}$ - and $7 \%$ of the C-1- $\alpha$-epimer were isolated ${ }^{6}$. Still's synthesis ${ }^{6)}$ clearly indicates that the absol. configuration at C-2' (pyrrolidine increment) must be $S$, the absol. configuration at C-1 (tetrahydro- $\beta$-carboline ring) remained to be established. Because Still $^{(6)}$ had both diastereomers at hand he was able to correlate both stereomers of woodinine with the diastereomers of the (twofold primary) amines 1-(piperidin-2yl)-1,2,3,4-tetrahydro- $\beta$-carboline ${ }^{7)}$. Still et al. "feel that compounds (woodinine and its diastereomer) probably exist in solution as hydrogenbonded structures,"6) (H-bond between $\mathrm{NH}$ of the indole part and the tert. amine of the pyrrolidine group).

We have some concerns about a H-bridge because neither protonation of the pyrrolidine- and the piperidine- $\mathrm{N}$-atom nor deuteriation of the indole- $\mathrm{NH}$-group (yielding indoleND) influenced the shape of the 1-H-signal: the configuration of woodinine (12a) may be independent of a H-bridge. Based on Dreiding models Still et al. ${ }^{6}$ correlate the coupling constants for $\mathrm{H}-1$ of woodinine (12a) ("singlet at $\delta=$ 3.52 for the $\mathrm{C}-1 \mathrm{H}$ "6); "3,60 (1H, s large)"3) (French word, meaning broad s)) and that of woodinine epimer ("doublet at $\left.\delta=3.17(\mathrm{~J}=10.0 \mathrm{~Hz})^{\text {"'6) }}\right)$ with the coupling constants of the piperidin-2-yl-tetrahydro- $\beta$-carbolines ${ }^{7)}$ (see above) and deduced 1-(R)-2'-(S)-configuration for woodinine (12a) and $1-(S)-2$ '- $(S)$-configuration for its diastereomer $\mathbf{1 2 b}$. The broad singlet in 12a observed by Païs $^{3)}$, Still ${ }^{6)}$, and one of us ${ }^{1)}$ may hide a coupling constant of $4-6 \mathrm{~Hz}$, especially because 1-H may couple with the $\mathrm{N}-\mathrm{CH}_{3}$-group: this line broadening, caused by the quadrupol relaxation of the ${ }^{14} \mathrm{~N}$ nucleus attached to the C-H-proton does not allow exact determination of a ${ }^{3} \mathrm{~J}$-coupling ${ }^{8}$. Determination of the absol. configuration at a center of chirality in the neighbourhood of a chiral center of known absol. configuration by ${ }^{1} \mathrm{H}-$ NMR-correlation, however, requires exact determination of the pertinent coupling constant.

This situation prompted us to check the stereochemical aspects of woodinine (12a) and its epimer. - We inhibited free rotation around the C-1 - C-2'-bond by cyclization adopting Dreiding's strategy ${ }^{9)}$ by twofold reaction of the secondary amines 13, 14, and 15 (obtained by hydrolysis of 11a, 11b, and 7a) (Scheme 3) with diethyl oxalate, leading to the piperazinediones 16,17 and 18 . Because the piperazin-di-on-substructure comprises two $\mathrm{sp}^{2}$-hybridized Catoms, we had not to bother about conformations as described by Misztal $^{7}$. In the piperazinedione $1614 \mathrm{~b}-\mathrm{H}$ resonates at $\delta=5.03 \mathrm{ppm}$ as a doublet with ${ }^{3} \mathrm{~J}=10.7 \mathrm{~Hz}$. - In the epimer $1714 \mathrm{~b}-\mathrm{H}$ shows a doublet at $\delta=5.46 \mathrm{ppm}$ with ${ }^{3} \mathrm{~J}=4.9 \mathrm{~Hz}$. According to the Karplus-Conroy-curve 10.7 $\mathrm{Hz}$ correspond to either $0^{\circ}$ or $180^{\circ} ; 4.87 \mathrm{~Hz}$ to $40^{\circ}$ or $130^{\circ}$. - We discriminated between the two possibilities by NOEexperiments: irradiation into the doublet at $\delta=5.03 \mathrm{ppm}$ $(14 \mathrm{~b}-\mathrm{H})$ of 16 increases the intensity of the indole NHsinglet at $\delta=10.96 \mathrm{ppm}$. The multiplet of $14 \mathrm{c}-\mathrm{H}$ was not influenced indicating that $14 \mathrm{~b}-\mathrm{H}$ and $14 \mathrm{c}-\mathrm{H}$ are nearly perpendicular to each other. - Similar NOE-measurements with the epimer 17 show that irradiation into the doublet of $14 \mathrm{~b}$ $\mathrm{H}$ at $\delta=5.46 \mathrm{ppm}$ increased the intensity of the $14 \mathrm{c}-\mathrm{H}-\mathrm{mul}-$ tiplet, indicating cis-standing protons at C-14b and C-14c.
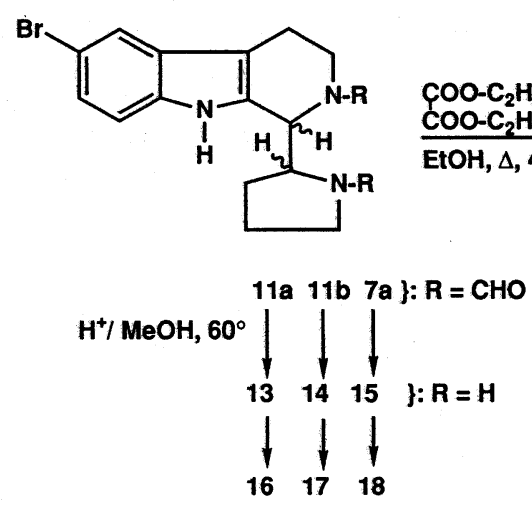

stereochemical specification

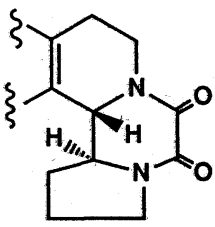

16

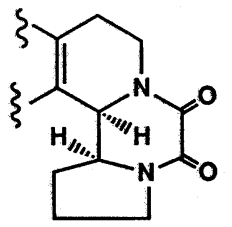

17

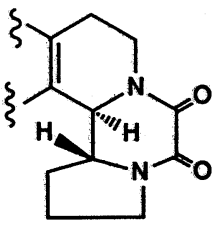

18

Scheme 3 
Irradiation into the $\mathrm{NH}$-frequency of $\mathbf{1 7}$ at $\delta=10.98 \mathrm{ppm}$ only increases the intensity of the $13-\mathrm{H}$ doublet at $\delta=7.38$ ppm.

Homo-decoupling of $14 \mathrm{c}-\mathrm{H}$ of $\mathbf{1 6}$ converts the doublet of $14 \mathrm{~b}-\mathrm{H}$ to a singlet (besides decoupling of the signal at 3.5 $\mathrm{ppm}$ ). Irradiation into the doublet of $14 \mathrm{~b}-\mathrm{H}$ at $\delta=5.03 \mathrm{ppm}$ simplifies the multiplet of $14 \mathrm{c}-\mathrm{H}$ at $\delta=3.69 \mathrm{ppm}$.

Because the bis-formamides 11a and 11b are unequivocally correlated as well with the bis-amines $\mathbf{1 3}$ and $\mathbf{1 4}$ as with woodinine (12a) and the enantiomer $12 b$ of $8 \mathbf{b}$ (no attacks at the centers of chirality) the stereochemistry of 12a and 12b is definitely established. Our results secure the conclusions of Still and coworkers ${ }^{6)}$.

Financial support of this project by Fonds der chemischen Industrie is gratefully acknowledged.

\section{Experimental Part}

General remarks: lit. ${ }^{1)}$.- $[\alpha]$-values at D-line and $20^{\circ} \mathrm{C}$, if not otherwise stated.

5-Bromotryptamine (1): lit. ${ }^{1)}$ and lit. cited there.

(R)-(+)-N-(tert-Butoxycarbonyl)-pyrrolidine-2-carboxaldehyde (2)

2 was prepared as described for its enantiomer ${ }^{1)}$ starting from D-proline. Data: lit. ${ }^{1)}$ and lit. cited there.

(R)-B-(5-Bromoindol-3-yl)-N-[N-(tert-butoxycarbonyl)-pyrrolidin-2-ylmethylidene]-ethylamine (3) and

$I-[(R)$-(N-tert-Butoxycarbonyl)pyrrolidin-2-yl]-6-bromo-1,2,3,4-tetrahy-

dro- $\beta$-carboline (4), mixture of diastereomers

Cf. lit. ${ }^{1)}$-- Formation of the imine group by molecular sieve improves the yield: The solution of $1.25 \mathrm{~g}(5.22 \mathrm{mmol}) 1$ and $1.04 \mathrm{~g}(5.22 \mathrm{mmol}) 2$ in 40 ml of absol. $\mathrm{CH}_{2} \mathrm{Cl}_{2}$ was stirred with molecular sieve 4 A under $\mathrm{N}_{2}$ for $1 \mathrm{~h}$ at room temp. After filtration and washing with absol. $\mathrm{CH}_{2} \mathrm{Cl}_{2}$, the solution of imine 3 was cooled to $-78^{\circ} \mathrm{C}$. $1.3 \mathrm{ml}(10.5 \mathrm{mmol}) \mathrm{F}_{3} \mathrm{CCOOH}$ were added dropwise during $2.5 \mathrm{~h}$ at $-78^{\circ} \mathrm{C}$, the solution was allowed to warm to $+20^{\circ} \mathrm{C}$ during $4 \mathrm{~h}$ under stirring, poured into ice water, alkalized with $2 \mathrm{~N}$ $\mathrm{Na}_{2} \mathrm{CO}_{3}$ at $0^{\circ} \mathrm{C}$, washed with water $(2 \times 20 \mathrm{ml})$, dried $\left(\mathrm{Na}_{2} \mathrm{SO}_{4}\right)$, and evaporated in vacuo. The residue was dried at room temp. and $0.05 \mathrm{~mm} \mathrm{Hg}$ : yellowish amorphous powder of $\beta$-carbolines 4. $2.18 \mathrm{~g}$ (99\%).- M.p. (crude product) $68-70^{\circ} \mathrm{C}$.- Analytical data: lit. ${ }^{1}$.

1-[(R)-(N-tert-Butoxycarbonyl)pyrrolidin-2-yl]-6-bromo-2-formyl-1,2,3,4tetrahydro- $\beta$-carboline $(\mathbf{5})$, mixture of diastereomers

This mixture of cpds. 5 was prepared as described for the diastereomers with $S$-configuration at pyrrolidine-C- $2^{1)}$ - Analytical data: lit. ${ }^{1}$.

\section{1-[(R)-Pyrrolidin-2-yl]-6-bromo-2-formyl-1,2,3,4-tetrahydro- $\beta$-carboline (6), mixture of diastereomers}

To the solution of $940 \mathrm{mg}(2.09 \mathrm{mmol}) 5 \mathrm{in} 10 \mathrm{ml}$ of absol. $\mathrm{CHCl}_{3} 10 \mathrm{ml}$ of $\mathrm{F}_{3} \mathrm{CCOOH}$ were added drop by drop at $0^{\circ} \mathrm{C}$ under $\mathrm{N}_{2}$ and stirring. After $9 \mathrm{~h}$ at $0^{\circ} \mathrm{C}$ the solution was diluted with ice water and basified with $2 \mathrm{~N}$ $\mathrm{Na}_{2} \mathrm{CO}_{3}$. The org. layer was separated, the aqueous phase was extracted with $\mathrm{CHCl}_{3}(2 \times 15 \mathrm{ml})$. The combined org. phases were dried $\left(\mathrm{Na}_{2} \mathrm{SO}_{4}\right)$

\footnotetext{
*) This nomenclature was deduced from that of a similar heterocycle: $S$. Misztal et al. ${ }^{7 b)}$.
}

and evaporated to dryness in vacuo: yellow powder which was dried at room temp. and $0.05 \mathrm{mg} \mathrm{Hg.:} 710 \mathrm{mg}(97 \%)$ which were directly converted to cpds. 7.- IR of 6-mixture (KBr): $\tilde{v}=3436$ (br., $\mathrm{NH}$ ); $1678 \mathrm{~cm}^{-1}$ (CO).

1-[(R)-N-Formylpyrrolidin-2-yl]-6-bromo-2-formyl-1,2,3,4-tetrahydro- $\beta$ carbolines (7), mixture of diastereomers, and separation of 7-diastereomers

To the solution of $697 \mathrm{mg}(2 \mathrm{mmol})$ crude 6 (see above) in $15 \mathrm{ml}$ of absol. $\mathrm{CH}_{2} \mathrm{Cl}_{2}$ were added under $\mathrm{N}_{2} 2.5 \mathrm{ml}$ acetic-formic anhydride ${ }^{1)}$ drop by drop at $0^{\circ} \mathrm{C}$ under stirring. After further $30 \mathrm{~min}$ at $0^{\circ} \mathrm{C}$ the mixture was alkalized by $\mathrm{Na}_{2} \mathrm{CO}_{3}$-solution to $\mathrm{pH}=9$, and the org. phase was separated, dried $\left(\mathrm{Na}_{2} \mathrm{SO}_{4}\right)$, and evaporated: $736 \mathrm{mg}$ white amorphous solid (98\%).

7-Diastereomers were separated by flash-chromatography $\left(\mathrm{SiO}_{2}\right.$; $\mathrm{CH}_{2} \mathrm{Cl}_{2}$ :hexane: $\mathrm{MeOH}=82: 15: 3-\mathrm{v} / \mathrm{v}$ ).

7a: $582 \mathrm{mg}$, colourless crystals, m.p. $215-220^{\circ} \mathrm{C}$ (dcp.) (EtOH, $\mathrm{Et}_{2} \mathrm{O}$, hexane). $[\alpha]=+126.5^{\circ}\left(\mathrm{CHCl}_{3}, \mathrm{c}=0.6\right)$. $\mathrm{C}_{17} \mathrm{H}_{18} \mathrm{BrN}_{3} \mathrm{O}_{2}$ (376.3) Calc. $\mathrm{C}$ $54.3 \mathrm{H} 4.82 \mathrm{~N} 11.2$ Found C $54.0 \mathrm{H} 4.86 \mathrm{~N}$ 11.0.- IR $(\mathrm{KBr}): \tilde{v}=3278$ $(\mathrm{NH}) ; 1665 \mathrm{~cm}^{-1}(\mathrm{CO}) .-\mathrm{MS}(70 \mathrm{eV}): \mathrm{m} / \mathrm{z}=377 / 375\left(10 \%, \mathrm{M}^{+\bullet}\right), 279 / 277$ $\left(9 ; \mathrm{M}-\mathrm{C}_{5} \mathrm{H}_{8} \mathrm{NO}\right)^{+}, 251 / 249(279 / 277-\mathrm{CO})^{+}, 98\left(100 ; \mathrm{C}_{5} \mathrm{H}_{8} \mathrm{NO}\right)^{+}, 70$ $\left(\mathrm{C}_{4} \mathrm{H}_{8} \mathrm{~N}\right)^{+\cdot}$.- $\left({ }^{1} \mathrm{H}-\mathrm{NMR}\right.$-spectra could not be interpreted, probably on account of ring chain tautomers or rotamers).

7b: $103 \mathrm{mg}$, m.p. $201-206^{\circ} \mathrm{C}$ (dcp.) $\left(\mathrm{EtOH}, \mathrm{Et}_{2} \mathrm{O}\right.$, hexane). $[\alpha]=-76.5^{\circ}$ $\left(\mathrm{CHCl}_{3}, \mathrm{c}=0.6\right) \cdot-\mathrm{C}_{17} \mathrm{H}_{18} \mathrm{BrN}_{3} \mathrm{O}_{2}$ (376.3) Calc. C $54.3 \mathrm{H} 4.82 \mathrm{~N} 11.2$ Found C 54.9 H $4.82 \mathrm{~N}$ 11.2.- IR (KBr): $\tilde{v}=3268(\mathrm{NH}) ; 1655 \mathrm{~cm}^{-1}(\mathrm{CO})$.

(S)-1-[(R)-N-Methylpyrrolidin-2-yl]-6-bromo-2-methyl-1,2,3,4-tetrahydro$\beta$-carboline (8a)

The solution of $400 \mathrm{mg} 7 \mathrm{a}$ in $6 \mathrm{ml}$ of absol. tetrahydrofurane (THF) was added drop by drop at $0^{\circ} \mathrm{C}$ to the suspension of $300 \mathrm{mg} \mathrm{LiAlH}_{4}$ in $6 \mathrm{ml}$ of absol. THF under $\mathrm{N}_{2}$. After reflux for $1.5 \mathrm{~h}$ the mixture was hydrolyzed by $\mathrm{Et}_{2} \mathrm{O} /$ water at $0^{\circ} \mathrm{C}$, the org. phase was dried $\left(\mathrm{Na}_{2} \mathrm{SO}_{4}\right)$ and evaporated in vacuo: oily material (homogenous according to tlc; $\mathrm{SiO}_{2} ; \mathrm{CH}_{2} \mathrm{Cl}_{2}: \mathrm{MeOH}=$ 94:6), which crystallized whilst standing at room temp.: $390 \mathrm{mg}(100 \%)$. Purification by column chromatography (cc) $\left(\mathrm{SiO}_{2} ; \mathrm{CH}_{2} \mathrm{Cl}_{2}: \mathrm{MeOH}=\right.$ 94:6), crystallization from $\mathrm{MeOH}$ : colourless crystals, m.p. $112-113^{\circ} \mathrm{C}$ (enantiomer of woodinine). $[\alpha]=+80.2^{\circ}(\mathrm{MeOH}, \mathrm{c}=0.6) .-\mathrm{C}_{17} \mathrm{H}_{22} \mathrm{BrN}_{3}$ (348.1) Calc. C 58.6 H 6.37 N 12.1 Found C 58.6 H 6.27 N 12.0.- IR-, mass-, and ${ }^{1} \mathrm{H}-\mathrm{NMR}$-spectra: identical with those of woodinine (12a).

(R)-1-[(R)-N-Methylpyrrolidin-2-yl]-6-bromo-2-methyl-1,2,3,4-tetrahydro- $\beta$-carboline ( $\mathbf{8 b})$

$40 \mathrm{mg}(0.106 \mathrm{mmol}) 7 \mathrm{~b}$ in $2 \mathrm{ml}$ of absol. THF were reduced with $40 \mathrm{mg}$ $\mathrm{LiAlH}_{4}$ in $1 \mathrm{ml}$ THF as described for 7a.- Work-up (see 8a) led to $38 \mathrm{mg}$ of a yellowish oil which was purified by $\mathrm{cc}\left(\mathrm{SiO}_{2} ; \mathrm{EtOAc}: \mathrm{CH}_{2} \mathrm{Cl}_{2}: \mathrm{MeOH}\right.$ $=40: 57: 3-\mathrm{v} / \mathrm{v})$ : wax like solid, $32 \mathrm{mg}(86 \%) .-[\alpha]=-18.3^{\circ}(\mathrm{MeOH}, \mathrm{c}=$ 0.6).- IR (film): $\tilde{\mathbf{v}}=3417 ; 2931 ; 2790 \mathrm{~cm}^{-1}$.- ${ }^{1} \mathrm{H}-\mathrm{NMR}\left(250 \mathrm{MHz}, \mathrm{CDCl}_{3}\right)$ : $\delta(\mathrm{ppm})=1.81-3.20(\mathrm{~m} ; 12 \mathrm{H}), 1.98\left(\mathrm{~s} ; 3 \mathrm{H}, \mathrm{NCH}_{3}\right), 2.46\left(\mathrm{~s} ; 3 \mathrm{H}, \mathrm{NCH}_{3}\right)$, 7.206 (s; 1H aromat.), 7.21 (s; $1 \mathrm{H}$ aromat.), 7.62 (br. s; 1H aromat.), 8.9 (br. s; $1 \mathrm{H}, \mathrm{NH}$, exchangeable).

Woodinine diastereomer $\mathbf{1 2 b}$ and improved preparation of woodinine (12a)

1-[(S)-(N-tert-Butoxycarbonyl)pyrrolidin-2-yl]-6-bromo-2-formyl-1,2,3,4tetrahydro- $\beta$-carboline $(\mathbf{9})$, mixture of diastereomers: see $8 \mathrm{a}+8 \mathrm{~b}$ in lit.1).

1-[(S)-(N-tert-Butoxycarbonyl)pyrrolidin-2-yl]-6-bromo-2-methyl-1,2,3,4tetrahydro- $\beta$-carboline (9')

When the mixture of 9-diastereomers was reduced with $\mathrm{LiAlH}_{4}$ in THF for $1 \mathrm{~h}$ under reflux (tlc control, no more cpd. 9) and worked up as usual, 
cpd. 9' was obtained.- M.p. $180-182^{\circ}$ (hexane/diisopropyl ether).- IR $(\mathrm{KBr}): \tilde{\mathbf{v}}=3316(\mathrm{NH}) ; 1667 \mathrm{~cm}^{-1}(\mathrm{CO}) .-{ }^{1} \mathrm{H}-\mathrm{NMR}\left(250 \mathrm{MHz}, \mathrm{C}_{2} \mathrm{D}_{2} \mathrm{Cl}_{4}\right): \delta$ $(\mathrm{ppm})=1.2(\mathrm{~s} ; 9 \mathrm{H}, \mathrm{Boc}), 1.69-4.15(\mathrm{~m} ; 12 \mathrm{H}), 2.46\left(\mathrm{~s} ; 3 \mathrm{H}, \mathrm{NCH}_{3}\right), 7.11$ $(\mathrm{d} ; \mathrm{J}=7.5 \mathrm{~Hz}, 1 \mathrm{H}, 8-\mathrm{H}), 7.18\left(\mathrm{dd} ; \mathrm{J}_{\mathrm{o}}=7.5 \mathrm{~Hz}, \mathrm{~J}_{\mathrm{m}}=1.8 \mathrm{~Hz}, 1 \mathrm{H}, 7-\mathrm{H}\right), 7.56$ $\left(\mathrm{d} ; \mathrm{J}_{\mathrm{m}}=1.8 \mathrm{~Hz}, 1 \mathrm{H}, 5-\mathrm{H}\right), 8.16$ (br. $\left.\mathrm{s} ; 1 \mathrm{H}, \mathrm{NH}\right) .-\mathrm{MS}(70 \mathrm{eV}): \mathrm{m} / \mathrm{z}=$ $435 / 433\left(1.3 \%, \mathrm{M}^{+\bullet}\right), 362 / 360(1), 265 / 263\left(100, \mathrm{M}-\mathrm{C}_{9} \mathrm{H}_{16} \mathrm{NO}_{2}\right)^{+}, 70$ $\left(\mathrm{C}_{4} \mathrm{H}_{8} \mathrm{~N}\right)^{+}$. - The pertinent diastereomer was not found by tlc systems and by ${ }^{1} \mathrm{H}$-NMR-spectroscopy.

\section{1-[(S)-Pyrrolidin-2-yl]-6-bromo-2-formyl-1,2,3,4-tetrahydro- $\beta$-carboline} (10), mixture of diastereomers

For preparation of cpds. 10 from cpds. 9 cf. cpd. 6 - 10 (mixture) was obtained as a white amorphous powder which was directly converted to the bis-formamides 11.- IR (10) $(\mathrm{KBr}): \tilde{v}=3407(\mathrm{NH}) ; 1659 \mathrm{~cm}^{-1}(\mathrm{CO})$.

1-[(S)-N-Formylpyrrolidin-2-yl]-6-bromo-2-formyl-1,2,3,4-tetrahydro- $\beta$ carboline (11), mixture of diastereomers

For preparation from amines $\mathbf{1 0} \mathrm{cf}$. cpd. 7.- Separation of diastereomers by flash chromatography (cf. cpd. 7).

\section{(R)-1-[(S)-N-Formylpyrrolidin-2-yl]-6-bromo-2-formyl-1,2,3,4-tetrahy- dro- $\beta$-carboline (11a)}

Colourless crystals, $\mathrm{m}$. range $220-226^{\circ} \mathrm{C}$ (ring-chain-tautomers?) (EtOH, $\mathrm{Et}_{2} \mathrm{O}$, hexane).- $[\alpha]=-140.8^{\circ}\left(\mathrm{CHCl}_{3}, \mathrm{c}=0.6\right) .-\mathrm{C}_{17} \mathrm{H}_{18} \mathrm{BrN}_{3} \mathrm{O}_{2}$ (376.3) Calc. C 54.3 H 4.82 N 11.2 Found C 53.9 H 4.88 N 10.9.- IR- and massspectra: cf. enantiomer $\mathbf{7 a}$.

(S)-1-[(S)-N-Formylpyrrolidin-2-yl]-6-bromo-2-formyl-1,2,3,4-tetrahydro$\beta$-carboline (11b)

Colourless crystals, m. range $203-208^{\circ} \mathrm{C}$ (dec.) (EtOH, $\mathrm{Et}_{2} \mathrm{O}$, hexane; ring-chain-tautomers?).- $[\alpha]=+72.8^{\circ}\left(\mathrm{CHCl}_{3}, \mathrm{c}=0.6\right)$.- Further data: enantiomer $\mathbf{7 b}$.

\section{Woodinine (12a)}

$\mathrm{LiAlH}_{4}$-reduction of 11a as described for 7a and usual work-up led to woodinine (12a), m.p. $112-113^{\circ} \mathrm{C}$, identical in all aspects with our reference sample ${ }^{1)}$.

(S)-1-[(S)-N-Methylpyrrolidin-2-yl]-6-bromo-2-formyl-1,2,3,4-tetrahydro$\beta$-carboline (12b)

12b was obtained from 11b (cf. conversion of 11a to 12a) as a yellowish wax-like material, m.p. $39-41^{\circ} \mathrm{C}$.- $[\alpha]=+19.7^{\circ}(\mathrm{MeOH}, \mathrm{c}=0.6)$.- Further data: enantiomer $\mathbf{8 b}$.

\section{1-(Pyrrolidin-2-yl]-6-bromo-1,2,3,4-tetrahydro- $\beta$-carbolines 13, 14, 15}

Cpds. 13, 14, and 15 were prepared from the pertinent bis-formamides 11a, 11b, and 7a as described for 11a (see below) (7b was not included on account of the small quantity available).

$37.6 \mathrm{mg}(1 \mathrm{mmol})$ 11a in $3 \mathrm{ml} \mathrm{MeOH}$ was refluxed with $0.5 \mathrm{ml} 3 \mathrm{~N} \mathrm{HCl}$ for $3.5 \mathrm{~h}$ under $\mathrm{N}_{2}$ in the dark, poured onto ice, and the aqueous solution so obtained was basified by $\mathrm{Na}_{2} \mathrm{CO}_{3}$ and extracted with $\mathrm{CH}_{2} \mathrm{Cl}_{2}$. The org. phase was dried $\left(\mathrm{Na}_{2} \mathrm{SO}_{4}\right)$ and evaporated in vacuo: $30 \mathrm{mg}$ (93\%) of 13; yellowish oil, which was cyclized to the pyrazinedione $\mathbf{1 6}$ without further purification.

13: MS $(70 \mathrm{eV}): \mathrm{m} / \mathrm{z}=321 / 319\left(0.03 \% ; \mathrm{M}^{+*}\right), 251 / 249(11 ; \mathrm{M}$ $\left.\mathrm{C}_{4} \mathrm{H}_{8} \mathrm{~N}\right)^{+}, 70\left(100 ; \mathrm{C}_{4} \mathrm{H}_{8} \mathrm{~N}\right)^{+}$.
Bis-amines 14 (from 11b) and 15 (from 7a) were prepared analogously and used for the next step without further purification.

\section{1,2,8,9,14b,14c-Hexahydro-11-bromo-pyrrolo[1' ',2' ':1',2']pyrazino-}

[4',3':1,2]pyrido[3,4-b]indol-5,6-(3H)diones 16, 17, 18*)

\section{$14 \mathrm{~b}(R), 14 \mathrm{c}(S)$-Diastereomer 16}

Under $\mathrm{N}_{2} 24 \mathrm{mg}(0.075 \mathrm{mmol})$ diamine 13 and $60 \mathrm{mg}$ diethyl oxalate in $1.5 \mathrm{ml} \mathrm{EtOH}$ were refluxed in the dark for $3.5 \mathrm{~h}$. During the reaction white crystals began to precipitate. After $3.5 \mathrm{~h}$ at room temp. the crystals were harvested, washed with ice cold EtOH and recrystallized from EtOH: 15.5 $\mathrm{mg}(55 \%)$, m.p. $338^{\circ} \mathrm{C}(\mathrm{EtOH})\left(\mathrm{dec}\right.$.). $[\alpha]=+251.6^{\circ}$ (DMSO, c $=0.6$ ). $\mathrm{C}_{17} \mathrm{H}_{16} \mathrm{BrN}_{3} \mathrm{O}_{2}$ (374.2) Calc. C $54.5 \mathrm{H} 4.31 \mathrm{~N} 11.2$ Found C $55.0 \mathrm{H} 4.40 \mathrm{~N}$ 11.2.- IR $(\mathrm{KBr}): \tilde{\mathrm{v}}=3284(\mathrm{NH}) ; 1671 \mathrm{~cm}^{-1}(\mathrm{CO}) .-{ }^{1} \mathrm{H}-\mathrm{NMR}(250 \mathrm{MHz}$, [D 6 DMSO): $\delta(\mathrm{ppm})=1.75-3.55(\mathrm{~m} ; 9 \mathrm{H}), 3.69(\mathrm{~m} ; 1 \mathrm{H}, 14 \mathrm{c}-\mathrm{H}), 4.75(\mathrm{~m}$; $1 \mathrm{H}, 8$-H eq.), 5.03 (d; J = 10.7 Hz, 1H, 14b-H), 7.23 (dd; $\mathrm{J}_{\mathrm{o}}=8.5, \mathrm{~J}_{\mathrm{m}}=2$ $\mathrm{Hz}, 1 \mathrm{H}, 12-\mathrm{H}), 7.37$ (d; J = $8.5 \mathrm{~Hz}, 1 \mathrm{H}, 13-\mathrm{H}), 7.68(\mathrm{~d} ; \mathrm{J}=2 \mathrm{~Hz}, 1 \mathrm{H}, 10-$ H), 10.96 (sharp s, $1 \mathrm{H}, \mathrm{NH}) .-\mathrm{MS}(70 \mathrm{eV}): \mathrm{m} / \mathrm{z}=375 / 373\left(8 \% ; \mathrm{M}^{+*}\right)$, $347 / 345$ ( 1 ; M - CO $)^{+\bullet}, 250 / 248$ (21; 6-bromo-3,4-dihydro- $\beta$-carboline), $70\left(100 ; \mathrm{C}_{4} \mathrm{H}_{8} \mathrm{~N}\right)^{+}$.

*) This nomenclature was deduced from that of a similar heterocycle: $\mathrm{S}$. Misztal et al. ${ }^{7 b)}$

\section{$14 \mathrm{~b}(S), 14 \mathrm{c}(S)$-Diastereomer 17}

The diastereomeric piperazinedione 17 was obtained from diamine 14 as described for the preparation of 16.- Colourless crystals, m.p. $260-263^{\circ} \mathrm{C}$ $\left(\mathrm{MeOH}, \mathrm{CHCl}_{3}\right) .-[\alpha]=-75^{\circ}\left(\mathrm{CHCl}_{3}, \mathrm{c}=0.4\right)$.- $\mathrm{IR}(\mathrm{KBr}): \tilde{\mathrm{v}}=3280(\mathrm{NH})$; $1669 \mathrm{~cm}^{-1}$ (CO).- ${ }^{1} \mathrm{H}-\mathrm{NMR}\left(250 \mathrm{MHz},\left[\mathrm{D}_{6}\right] \mathrm{DMSO}\right): \delta(\mathrm{ppm})=1.75-3.69$ (m; 9H), $4.30(\mathrm{~m} ; 1 \mathrm{H}, 14 \mathrm{c}-\mathrm{H}), 4.75(\mathrm{~m} ; 1 \mathrm{H}, 8-\mathrm{H}$ eq.), $5.46(\mathrm{~d} ; \mathrm{J}=4.9 \mathrm{~Hz}$, $1 \mathrm{H}, 14 \mathrm{~b}-\mathrm{H}), 7.22\left(\mathrm{dd} ; \mathrm{J}_{\mathrm{o}}=8.6 ; \mathrm{J}_{\mathrm{m}}=2 \mathrm{~Hz}, 1 \mathrm{H}, 12-\mathrm{H}\right), 7.38(\mathrm{~d} ; \mathrm{J}=8.6 \mathrm{~Hz}$, $1 \mathrm{H}, 13-\mathrm{H}), 7.62$ (d; J = $2 \mathrm{~Hz}, 1 \mathrm{H}, 10-\mathrm{H}), 10.98$ (sharp s; 1H, NH).

The enantiomer of $\mathbf{1 7}$ has not been prepared on account of economic reasons.

\section{4b $(S), 14 \mathrm{c}(R)$-Diastereomer 18 (enantiomer of 16)}

Cyclization of $\mathbf{1 5}$ as described for $\mathbf{1 3}$ led to the piperazinedione 18.M.p. $336^{\circ} \mathrm{C}(\mathrm{EtOH}) .-[\alpha]=-247.4^{\circ}(\mathrm{DMSO}, \mathrm{c}=0.6) .-\mathrm{C}_{17} \mathrm{H}_{16} \mathrm{BrN}_{3} \mathrm{O}_{2}$ (374.2) Calc. C 54.5 H 4.31 N 11.2 Found C 54.9 H 4.29 N 11.2.- Further data: enantiomer 16.

\section{References}

1 S. Mahboobi, Arch. Pharm. (Weinheim) 1992, 325, 249-250.

2 a) S. Mahboobi, Pharm. Unserer Zeit 1991, 20, 129. b) W. Meindel, R. Laske, Arch. Pharm. (Weinheim) 1989, 322, 133136.

3 C. Debitus, D. Laurent, M. Païs, J. Nat. Prod. 1988, 51, 799-801.

4 K.L. Rinehart Jr., J. Kobayashi, G.C. Harbour, R.G. Hughes Jr., S.A. Mizsak, T.A. Scahill, J. Am. Chem. Soc. 1984, 106, 1524-1526.

5 K. Bláha, Z. Koblicova, J. Trojanek, Collect. Czech. Chem. Commun. 1974, 39, 3168-3176.

6 J. McNulty, I.W.J. Still, Tetrahedron Lett. 1991, 32, 4875-4878.

7 a) S. Misztal, M. Dukat, Heterocycles 1985, 23, 2271-2275. b) S. Misztal, M. Dukat, J.L. Mokrosz, J. Chem. Soc. Perkin Trans. 1, 1990, 2311-2315.

8 H. Günther, NMR-Spektroskopie, G. Thieme Verlag, Stuttgart 1973, p. 286 .

9 a) M.A. Siegfried, H. Hilpert, M. Rey, A.S. Dreiding, Helv. Chim. Acta 1980, 63, 938-961.

b) Y. Okamoto, D. Dirnberger, Th. Burgemeister, G. Dannhardt, W. Wiegrebe, Arch. Pharm. (Weinheim) 1986, 319, 1122-1129. 